\title{
TRADISI RITUAL SEBLANG DALAM PERSPEKTIF HUKUM ISLAM DI DESA OLEHSARI KECAMATAN GLAGAH BANYUWANGI
}

\author{
Oleh : \\ Muhammad Jufri ${ }^{1}$ \& Zulham Nur Hali \\ Fakultas Syari'ah IAI Ibrahimy Situbondo \\ m.jufritujuhtiga@gmail.com \\ zulhamnurhali@1995@gmail.com
}

\begin{abstract}
:
Seblang dance is a tradition practiced by some communities Banyuwangi that has value and a purpose, namely as a place of religious expression, as a belief system that aims to find a relationship with the spirit world. Some of the values contained in the Seblang dance tradition has a good purpose is certainly not contrary to the teachings of Islam as well.
\end{abstract}

Key Words : Ritual Seblang, Islamic Legal Perspective

\section{A. Pendahuluan}

Kebiasaan atau adat-istiadat tersebut pada dasarnya berbeda pada setiap tempat maupun golongan dalam masyarakat. Oleh karena itu, kebiasaan tidak perlu ditaati oleh semua penduduk dalam suatu wilayah Negara. Ada juga kebiasaan kedaerahan atau local. Kebiasaan kedaerahan itu dilakukan oleh penduduk suatu daerah, kota, atau bagiannya. Adat memang tidak pernah lepas dari kehidupan kita. Adatpun selalu menjadi suatu polemik yang sulit untuk dipecahkan, bahkan tidak jarang menjadi momok yang dinilai bid'ah dlalalah oleh sebagian cendikiawan kelas ringan. Padahal jika kita lihat dari kacamata sejarah, kesuksesan islam di jawa karena dapat menjadikan adat sebagai lahan dakwah. ${ }^{2}$ Izzuddin Ibnu Abdissalam memberikan komentar, bahwa semua problem fiqqiyah terfokus pada jalbul mashalih wa dar'ul mafasid. Karena itu Imam Malik menggunakan maslahah mursalah dalam menetapkan hukum, dan ulama sepakat bahwa 'urf atau adat sebagai salah satu dasar penetapan hukum.

Dengan demikian, islam mengakui 'urf atau adat sebagai sumber hukum, karena pada kenyataannya adat kebiasaan telah memainkan Situbondo.

1 Dosen dan Dekan Fakultas Syari'ah Institut Agama Islam Ibrahimy Sukorejo

2Ifrosin, 2007. Fiqh Adat (tradisi masyarakat dalam pandangan fiqh). Jawa Tengah: Mukjizat. hlm. 5. 
peranan penting dalam mengatur lalu lintas hubungan tata tertib sosial di kalangan masyarakat. Karena itulah, hal-hal yang tidak bertentangan dengan perinsip aqidah dan tauhid serta tidak bertentangan dengan rasa keadilan dan kemanusiaan, maka sariat islam membiarkan hukum adat berjalan terus, bahkan menetapkan dalam kerangka Islam itu sendiri. Sudah saatnya ilmuan Islam untuk memanfaatkan adat-istiadat tanpa harus melawannya, dan sudah saatnya adat tidak menjadi penghalang bagi dakwah. Sangat disesalkan ada sebagian golongan di Indonesia yang berpikiran cupet, bahwa adat adalah ajaran baru yang perlu diperangi. Padahal, Rasulullah saw. Tidak melarang suatu hal yang baik sebagaimana sabdanya,

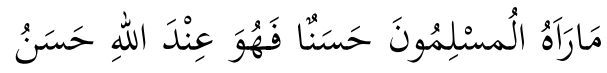

"sesuatu yang dilihat baik oleh orang muslim maka baik menurut Allah"3

Dari pernyataan tersebut, jika melihat secara historis-ideologis orang Indonesia dahulu kala, khususnya pulau jawa, mereka rata-rata penganut Agama Budha, Hindu, dan penyembah berhala. Mungkin dapat dibayangkan betapa sulitnya ajaran baru bisa diterima masuk, khususnya islam pada waktu itu. Bahkan lebih tragis lagi, karena kondisi pada waktu itu mayoritas penduduk jawa adalah abangan. ${ }^{4}$ Coba kita pikir, apa mungkin ada agama baru yang dapat diterima pada waktu itu? Maka jawabannya, sama sekali tidak mungkin. Namun kenyataanpun terjadi dan dapat kita rasakan saat ini, berbalik seratus persen. Kebanyakan orang jawa beragama Islam, bahkan ada yang mendapatkan title mufti mekkah, yaitu Syekh Nawawi dari Banten.

Ketika melihat adanya teks al-Qu'ran bahwa; al-Qur'an diturunkan kepada Nabi Muhammad melalui malaikat jibril secara brtahap sesuai dengan konteks masyarakat arab saat itu, bahkan tidak jarang al-Qur'an datang dalam bentuk jawaban atas pertanyaan masyarakat Arab menyangkut persoalan waktu tertentu, dan al-Qu'ran melanjutkan dengan

\footnotetext{
${ }^{3}$ Mahmud Ibrahim Muhammad. Al-Madkhal ila Al-Qawa'id Al-Fiqhiyah AlKulliyah.(Dar 'Aman, 1998.). hlm.109.

${ }^{4}$ Manusia keras kepala yang tidak pernah mau menerima kesalahan, dan dalam bertindak hanya mengedepankan emosional tanpa rasional. Dengan tepat professor Bahtiar telah mengemukakan (1973: 80-90) bahwa penggunaan istilah-istilah Abungan, santri, priyai untuk mengklasifikasikan masyarakat jawa dalam golongan agama tidak tepat, karena ketiga golongan tersebut bersumber pada klasifikasi yang sama (abangan dan santri adalah penggolongan yang dibuat menurut tingkat
} 
jawaban dan penjelasan menyangkut persoalan yang ditanyakan masyarakat tersebut. Hal ini menunjukkan denga jelas bahwa kondisi sosial menentukan turunnya teks al-Qur'an, dengan kata lain antara teks dan konteks saling berkaitan. Oleh karena itu, sejak semula yang direspon oleh suara langit adalah tradisi bumi. al-Qur'an yang kemudian terbentuk dengan korpus resmi dengan beribu bunyi teksnya semua untuk menjawab persoalan yang timbul saat itu. Yakni problematika yang dialami oleh bangsa arab pada awal perkembangan Islam. Tentu saja yang direspon adalah adat kebiasaan masyarakat Arab.

Adat pada saat ini sudah mencapai fase modern, dengan penuh karya yang beraneka ragam serta memiliki kreatifitas sesua dengan perubahan zaman. Yang mestinya, memiliki budaya dan tradisi yang berbeda antara satu Negara dengan Negara lain, antara satu daerah dengan daerah lain. Seperti halnya daerah banyuwangi yang memiliki aneka ragam budaya dan tradisi, yang mana budaya dan tradisi tersebut sangat lekat dengan keadaan masyarakat daerah banyuwangi. Salah satu tradisi yang ada di daerah banyuwangi ialah seblang. Dimana seblang sendiri terletak di Desa Olesari Kecamatan Glagah Kabupaten Banyuwangi. Dimana seblang dilaksanakan setiap satu tahun sekali setelah hari raya idul fitri, serta banyak ritual-ritual yang harus dilakukan.

\section{B. Sejarah Tradisi Ritual Seblang}

Upacara adat Seblang di desa Olehsari telah tercatat di pemerintahan sejak tahun 1930 yang ditangani oleh asisten Wedono Glagah. Tetapi yang tercatat dalam register itu bukan tentang seblangnya melainkan tentang pendemi (penyakit) yang menjalar di desa Olehsari. Sakit pagi malam meninggal, sakit malam pagi meninggal, maka masyarakat Olehsari atau ulih-ulihan yang di pimpin oleh Saridin, melakukan upacara seblang secara besar-besaran. Saridin bertindak juga sebagai pawang atau dukun yang menunjuk Jamilah atau Millah sebagai penarinya. Makna dari seblang itu sendiri adalah sebelnya biar ilang, maksudnya biar terhindar dari segala mala petaka. ${ }^{5}$ Pelaksanaan upacara adat seblang di desa Olehsari yang di laksanakan pada hari raya idul fitri. ${ }^{6}$ merupakan suatu manifestasi sejarah untuk di teliti aspek perkembangannya. Sebab berbeda dengan adat yang ada pada umumnya yang dilaksanakan pada bulan suro, seperti pada upacara adat lain

\footnotetext{
${ }^{5}$ Wawancara (Saridin), Banyuwangi 23 Maret 2016.

${ }^{6}$ Ibid
} 
seperti petiklaut, dan kebo-keboan. Sebab upacara adat seblang yang bernuansa kehinduan dilaksanakan pada hari besar islam.

Produk budaya lokal Banyuwangi telah mengalami proses yang cukup lama dan panjang, sepanjang perjalanan sejarah Blambangan sebagai kerajaan hindu trakhir diujung timur pulau jawa, sebab sebelum menjadi bagian dari kerajaan Majapahit. Blambangan tidak pernah lepas dari incaran kerajaan-kerajaan lain yang tertarik dengan kondisi geigrafis yang strategis dan subur. Serangkaiaan hubungan dan penaklukan oleh kerajaan lain menyebabkan masyarakat memiliki pola budaya tersendiri sebagai masyarakat multi etnik yang mampu mengolah keragaman budaya.

Penyerapan dan pesilangan budaya asli dengan budaya lain tidak hanya akibat perang, tetapi juga hubungan melalui perdagangan dengan saudagar-saudagar dari Bugis, Melayu, Mandar, Madura, Inggris, Cina, dan Arab. Terutama yang berhubungan dengan Syeh Wali Lanang yang memperistrikan Sayu Sekar Dalu, putri tunggal pangeran Senbayu raja Blambangan dan melahirkan putra bernama Raden Paku atau Jaka Samudra yang kemudian menjadi wali yang berkedudukan di Gersik dengan julukan Sunan Giri. Selain menyebarkan islam para wali juga mendekati masyarakat dengan mengadopsi sejumlah kesenian dan adat istiadat sehingga tampak islami, selain itu juga par pendatang dari Bugis, Melayu, dan Mataram berpengaruh sangat besar dalam penyebaran Agama islam di Blambangan. Tetapi masyarakat Blambangan sendiri tampaknya masih mengikuti kepercayaan lamanya yang berlatar belakang Agama Hindu, hal itu terlihat sangat jelas pada upacara adat seblang dan sejumlah adat istiadat lain.

Perjalanan sejarah yang cukup panjang itu membentuk karakter budaya yang berbeda dengan karakter jawa. Ciri khas dari karakteristik yang menonjol adalah"sinkrealisme", yaitu dapat menerima dan menyerap budaya masyarakat luar untuk di produksi kembali menjadi budaya"using", suatu julukan bagi masyarakat using yang tersisah oleh masyarakat pendatang terutama pendatang dari mataram, budaya masyarakat using sangat kental dengan kekuatan super natural yang bernilai magic. Termasuk yang sangat menonjol upacara adat seblang. Sejarah seblang kalau dikaitkan dengan sejarah perjuangan rakyat Blambangan melawan kompeni Belanda, boleh jadi perkembangannya setelah perang puputan bayu 1771, sebab kalau dilihat bentuk yang disimbolkan dalam gerakan dengan sejumlah sair-sair yang dilantunkan,

$8 \mid$ JURNAL LISAN AL-HAL 
merupakan kesatuan yang tak terpisahkan dengan sejarah seblang itu sendiri.

Manifestasi itu diperlambangkan dalam gerakan dan sair. Penari seblang melakukan gerakan dalam keadaan tidak sadar selama hamper 5 jam $^{7}$, di depan bangunan sanggar yang bergantungan berbagai macam hasil bumi yang ada di desa Olehsari. Penari seblang dalam keadaan tidak sadar, telah dipersiapkan diarena dengan kepulan asap yang penuh dengan dupa, sehingga membuat sekitar arena terkesan penuh dengan misreri, kemidian penari seblang mulai bergerak di damping pawang dan para sinden yang duduk bersimpuh siap dengan alat tabuhnya.

Secara empirik sair itu merupakan rangkaian sejarah perang puputan bayu dalam kajian epilog dan prolognya yang digerakkan oleh tiga tokoh pahlawan yang telah diajukan sebagai pahlawan nasional, yaitu Wong Agung Wilis, Pangeran Jaga Pati, dan pahlawan Putri Sayu Wiwit yang puncak kemenangannya pada tanggal 18 Desember 1771. Maka bentuk gerakan dan sair itu merupakan kajian tersendiri sebagai sejarah seblang dalam perkembangannya yang sudah mapan sampai sekarang ini.

Perangkat upacara adat seblang cukup bervariasi, bukan sekedar simbol, tetapi merupakan nilai spiritual yang harus dilengkapi secara utuh. Selain selamatan pra upacara dalam situs-situs tertentu atau dirumah penduduk atau selamatan pasar upacara yang untuk membersihkan diri yang bersifat pribadi. Maka perangkat lain yang sangat vital adalah "omprog" yaitu bagian dari busana yang menentukan identitas seblang, berupa mahkota ${ }^{8}$.adapun fungsi dari omprog adalah untuk menutup bagian kepala sehingga rambutnya tidak kelihatan rambutnya. Disamping itu juga berfungsi untuk menampilkan kesyakralannya upacara adat seblang itu dengan bentuk yang indah.

\section{Omprog Seblang}

Omprog seblang terbuat dari bahan alami berupa tetumbuhan yang ada di desa, terdiri dari dedaunan da sejumlah bunga-bungaan, dedaunan itu berupa pupus daun pisang, pupus daun pinang, daun nanas, dan daun jambu. Kegitan mebuat omprog dilakukan setiap hari sepekan atau selama proses upacara adat seblang itu berlangsung. Omprog yang telah digunakan selama upacara adat, sudah tidak digunakan lagi sebab bagian bunga yang menjadi perhiasannya telah di perebutkan orang untuk sesuatu yang dipercaya membawa berkah.

7 Observasi, Banyuwangi 15 Maret 2016

8 Wawancara, Banyuwangi 23 Maret 2016. 
Kerja pertama yang dilakukan dalam membuat omprog yaitu membuat kerangka kepala yang terbuat dari pilahan bambu yang telah dihaluskan, sehingga lentur dan mudah ditekuk. Bambu itu dibentuk menyulam menjadi segi empat atau mirip dengan tudung kepala semacam peci. Diluar kerangka itu dipasang rambut-rambutan dari pupus daun pisang yang telah diiris menyamping naik turun, sehingga menjadi helai daun yang tampak seperti ikal rambut yang bergelombang yang panjangnya sampai ke bahu. Rambu-rambutan yang terbuat dari pupus daun pisang itu di buat sebanyak lima lapis, dan setiap lapis dipasang pada bagian tepi dan di sobek kecil-kecil dengan pisau pemotong, sehingga membentuk rambut. Lapisan pupus daun pisang yang lain dipasang di sela-sela pupus pisang yang lain dengn mengunakan benang jahit sehingga bagian belakan dan bagian sebelah kanan dan kiri merupakan ikatan dan lapisan dari keseluruhan asesoris omprog. Untuk memotong daun nanas menjadi dua irisan, masing-masing potongan sekitar $15 \mathrm{~cm}$ dan kedua daun nanas itu diletakkan pada bagian atas depan pada rangka kepala yang tertutup dari rambut-rambutan dari daun pisang, tepatnya pada sisi kiri dan kanan sehingga menyerupai tanduk. Diantara dua tanduk nanas itu, diletakkan sebuah cermin kecil yang berbentuk setengah busur dengan ukuran diameter sekitar $5 \mathrm{~cm}$ sehingga terlihat seperti mata9.

Omprog hanya mempunyai makna secara khusus hanya untuk mahkota seblang, arti lain sangat sulit untik bisa dijabarkan, sejumlah kosa kata dari bahasa Kawi, bahasa Jawa kuno, bahasa Bali, dan bahasa Sunda tidak di jumpai istilah kata "omprog" tetapi bentuk mahkota lain yang dipakai oleh penari adalah kuluk, tengkuluk, jamang, jamanganan. Tetapi ada beberapa orang yang terpengaruh dengan jumlah kosa kata bahasa Inggris yang diadopsi ke bahasa Using yang menyebutkan omprog serapan dari kata "on proug" yang berarti diatas keturunan leluhur, tetapi pengertian itu hanya pendapat iseng. Tetapi omprog seblang sangat mengandung nilai ritual yang bermakna sacral penuh dengan mistik. Sedangkan busana penari seblang hamper sama dengan busana penari gandrung, tetapi tatariasnya yang digunakan masih tradisional.

\section{Genjot}

Genjot mempunyai arti khusus sebagai tempat yang dibuat agak lebih tinggi terbuat dari bahan bambu atau kayu sehingga terlihat dari jarak jauh. Upacara adat seblang sebagai "tuntunan" yang mengandung

${ }^{9}$ Observasi, 10 Juni 2016

10 JURNAL LISAN AL-HAL 
kearifan lokal, di pentaskan di halaman rumah penari seblang atau di halaman rumah pawang ${ }^{10}$. Berhubung tontonan itu dihadiri orang banyak, maka arena pentas itu kurang memenuhi syarat maka pendukung adat punya gagasan untuk mendirikan genjot di tempat yang luas dan permanen dengan persyaratan menghadap ketimur.

Genjot yang menghadap ketimur itu berbentuk setengah lingkaran, bntuk itu mengan dung nilai kepercayaan, bahwa tuntunan yang disampaikan oleh seblang merupakan bagian dari kerifan untuk bergotong royong, dan arah timur mengandung makna awal dari sesiatu kehidupan baik arahnya maupun kekuatannya. Genjot prmanen yang terletak di timur desa dan menghadap timur merupakan tempat yang didasarkan pada tuntunan para leluhur.

\section{Perangkat Pawang Arwah}

Upacara adat seblang yang syarat dengan nilai magic maka keberadaan pawang tidak hanya seorang, tetapi sejumlah orang mempunyai penugasan khusus dalam upacara adat itu dengan nama yang berbeda bedasarkan penugasan masing-masing antara lain pengundang, pengudang, penjamu, perias, pengiring, tetapi kesemuanya dalam pengawasan seorang dukun atau pawang, umumnya mereka merupakan kerabat dekat dengan sang penari seblang terdahulu atau penari seblang sesudahnya, yang biasa disebut "mage beroyo" atau masih sedarah tidak mesti turunan langsung. Pawang atau dukun memiliki peranan penting pada pelaksanaan upacara adat seblang baik pra upacara maupun pasca upacara.

Tugas yang sangat berat yaitu mendatangkan atau memanggil "Arwah" disaat penari seblang sudah berada di atas arena dan disaksikan oleh ratusan orang yang menontonnya untuk memperoleh "tuntunan". Mempersiapkan segala macam sesaji dan memuliakan kesadaran penari pengaruh arwah. Sedangkan pawang yang lain punya tugas khusus untuk mengundang leluhur guna menetapkan hari dan penari.

Pawang pengundang selalu melibatkan istrinya sebagai medium tempat arwah leluhur memasuki tubuhnya sedangkan pawang pengundang diperankan oeh beberapa orang untuk mengundang atau membuat tidak sadar para penari sebrang agar tetap menari mengikuti gending yang dilantunkan para sinden.

10 Wawancara, 23 Maret 2016 
Pawang penjamu terdiri dari beberapa perempuan yang bertindak sebgai penerima tamu yang berada ditubuh penari seblang, mereka selalu berada di kanan kiri tempat penari seblang duduk.

Pawang perias biasanya merangkap sebagai pawang pengiring. Pawang perias merupakan pawang pembuat omprog yang satu keturunan dengan pawang sebelumnya, sedangkan pawang pengiring merupakan mantan sinden yang masih hafal dengan gending-gending seblang, mereka mengiringi penari seblang sejak dari rumahnya kerumah pawang perias dari rumah pawang perias sampai ke atas pentas dan jika diperlukan mengiring tarinya dan mengiring gendingnya.

\section{Gamelan, Yoga, dan Sinden}

Penampilan seblang diatas pentas yang diiringi oleh seperangkat gamelan tradisional terdiri dari sepasang gendang, tiga buah saron, sepasang gong besar dan kecil. Gamelan itu dimainkan oleh empat sampai lima orang yoga, seorang memainkan gendang, seorang memainkan gong, dan dua orang memainkan saron, dan seorang lagi sebagai pengudang yoga. Para yoga itu umumnya masih sedarah dengan para penari seblang, mereka mampu memainkan gamelan dengan menggunakan penjiwaan yang mendalam tentang gending-gending yang harus di nyanyikan oleh para sinden. Komposisi alat itu berada di bawah payung agung dengan posisi yang berbeda, gendang menghadap timur laut, gong menghadap arah tenggara, dua buah saron menghadap barat daya, sedangkan saron yang lain menghadap ke barat laut, sedangkan para sinden bersifat generative. ${ }^{11}$ sejumlah Sembilan orang hamper setiap lima tahun terlihat wajah baru dan masih muda berusia sekitar dua puluh sampai 30 tahun.

\section{Sesaji dan Perapen}

Sesaji yang disaratkan dalam upacara adat seblang terdiri dari berbagai tujuan dan cara dengan nama yang berbeda, sesaji buangan, sesaji peras, sesaji kinang, sesaji poro bungkil, sesuai dengan namanya masing-masing sesaji maka sesaji buangan adalah sesaji yang harus dibuang pada tempat-tempat tertentu pada suatu situs yang dipercaya membawa berkah, sesaji yang dibuang terdiri dari kembang telon, kepala ayam, berutu, jeroan, dan ragi kuning semua sesaji itu diletakkan disumber air sebagai lambang kehidupan.

11 Observasi, 12 Juli 2016 
Sesaji peras merupakan bentuk kehati-hatian untuk memanfaatkan sesuatu yang diperolehnya dari hasil usaha yang telah dikerjakan, berlambang dari pohon kelapa yang terdiri dari empal, batang, daun, janur, buah, beluluk sampai pada lidinya. Suatu lambing kehidupan pisang raja merupakan kekuasaan seperti raja dan pulau jawa, merupakan kehalusan dan kemanisan. Sesaji poro bungkil merupakan sesaji yang di buat dari hasil bumi yang merupakan manifestasi rasa syukur atas keberhasilan kerja selama itu. Sesaji poro bungkil merupakan sesaji untuk keselamatan acara seblang dengan menggantungkan sejumlah parah gantung dan para pendem diatas sangggar atau di atas bangunan yang di buat untuk adat seblang dan harus terlihat jelas oleh penontn dan penari seblang.

Perapen atau perapian merupakan medium tersendiri yang secara khusus dibuat dan diletakkan pada tertentu untuk membuat asap dengan aroma tertentu, terbuat dari gerabah dalam bentuk cawah yang berlubang yang disanggah dengan satu kaki yang melebar. Besarnya bisa berdiameter asbak atau sangat kecil berdiameter uang logam yang terpenting dalam perapian itu, adalah kepulan asapnya yang cukup banyak dengan aroma yang menyengat, untuk itu bahan yang digunakan selain arang dan kayu tertentu yang dibakar bersama sabut kelapa yang masih segar, sehingga asap yang ditimbulkan bisa membuat yang menghirup bisa pening dan menimbulkan suasana mistik yang mencekam lingkungan ${ }^{12}$.

\section{Gending-Gending Mantra Seblang}

Gending-gending mantra seblang adalah lagu-lagu dalam upacara adat seblang yang dibawakan oleh sejumlah sinden. Lagu-lagu seblang banyak mengandung nilai misteri, sejumlah kosa katanya sulit di artikan, keculi terkati dalam suatu kalimat itupun dalam batas penafsiran dan bukan arti yang sebenarnya. Gending-gending mantra seblang memiliki sejumlah judul tetapi dari sejumlah judul itu banyak yang dipenggal dalam sub judul yang tidak berjudul. Kosa kata semacam "liya-liyu, ngelemar ngelemir, ayun - ayun emping- emping, erang - erang, cempeluk dan masih banyak lagi" keculi jika itu merupakan kata wangsalan dan basanan seperti pada gending "seblang lukinto", damargunung mengarah pada bintang atau bintang yang berarti ketang - ketang atau untung - untung. Sumber mega mengarah pada udan atau hujan yang berarti edan atau gila. Mendung putih mengarah pada mega yang berarti taga. Cermeh putih

12 Ibid 
mengarah pada buah katu yang berarti kantru - kantru yang sama dengan temangu - temangu, belimbing bumi mengarah pada buah wesa yang berarti susah ${ }^{13}$. Misteri lain dalam gending-gending seblang terdapat pada sebagian dari lagu -lagu yang pendek, merupakan bentuk kalimat yang memiliki potensi untuk kata mantra, seperti gending "kembang pepe kembang durmo" untuk melepaskan arwah dari tubuh penari seblang.

Adapun gending-gending mantra seblang sebagai berikut:

a) Seblang Lokento

Seblang-seblang yo lokento / Sing kang dadi encakono

b) Liliro Kantun

Liliro kantun, sak kantuli liliro / Yugo yo sapanen yo dayoh riko / Mbok sur kubo milu tomo

c) Cengkir Gadhing

Cengkir gadhing, padusane mbok widodari, / Yo aduso yo lengganglenggung / Milu ganti sak kusuksan

d) Podho Nonton Pupuse

Podho nonton pupuse gedhang / Garise yang ring kene ono uwite / Ring pasregan akeh uwite

e) Podho Nonton Pudak Sempal

Podho nonton / Pudak sempal ring lelurung / Lambeyane poro putro / Poro putro kejuluk ring kedhung lewung / Yo jalane jolo sutro

f) Kembang Menur

Kembang menur / Melik-melik ring bebentur / Sun siram / Siram ulum / Sun petik mencirat ati

g) Kembang Gadhung

Kembang gadhung segulung di towo sewu / Nora murah nora larang / Kang nono wong adol kembang / Wong adol kembang yo barise ring / Temenggungan / Isun iring paying agung / Lakonane membat mayun

h) Kembang Pepe

Kembang pepe merambat ring kayu arum / Sang arumo membat mayun / Kang pepe yo ngajak lungo / Ngajak lungo mbok penganten / Kariyo dalu menjot-menjot jare lakune / Kariyo ngeluru lare-lare / Turokno ring perahu / Lurubono ring wono cindhe / Kang kumendhung ngalan seni

i) Lembang Dermo

13 Ibid

14 JURNAL LISAN AL-HAL 
Kembang dermo wiyayate mbok widodari / Yo kurmo tundha pitu / Ganjarane wongo perang / Wongo perang yo sampinge yo kalak ijo / Yo pinunjang surat ati / Luntrik-luntrik tibo ndodok

j) Layar Kumendhung

Layar kumendhung ombak umbul ring segoro / Segorane yo tawang agung / Tumenggung nunggang kereto

k) Ratu Sebrang

Ratu sebrang kang nunggang pendoko / Sino mundhuk-mundhuk / Yo kebo ladis sak pecute, joko kuwung

l) Kebyar-Kebyur

Kebyar-kebyar geni murub ring perahu / Urubono ring wono cinde / Kang tumandang ngelangsani

m) Baguse

Baguse yo bagus nyoman / Iringan dada kurasi / Kurasine you mar padang / Pendarungan tamansari.

n) Sekar Jenang

Sekar jenang meundang ndadari kuning / Agung alit temuruno / Ndadari turun maundang

o) Ayun-Ayun

Ayun-ayun kesilir badang pendek sang kasngoni / Wayahe penganten anyar sang kidul manyondro / Wayang / Yo damar yo damar ulan memantesi

p) Tambak

Amba-tambake ngedung / Udane ngarso maliki tanjung / Sak tanjung juragan bawang / Yo egel yo egelane sak juragan

q) Petung

Petung wuluh barise sifat kang kumandhang / Yo ring cotet akeh wong bagus / Ngelakoni loleng-loleng

r) Punjari

Punjari kembang petangsul / Kang becik yo riko kembang duren / Sangkal yo lanya lunyu / Lentak lentok lentak lentok

s) Sambung Laras

Sambung larasesir gulung kembang kencane / Akeh kembang ring sinikir / Uwohe kumulo inten

t) Ayu Kundur

Ayu kundur kecape wadahe riko / Riko ganti melik-melik / Kang ngenteni atur-atur / Kumantur sun tanpanono / Luberatun yo senggeh / Niku badanipu dipun cutet

u) Kembang Abang 
Kembang abang selebrang / Telo ring kasur seleregan / Balenono sun anteni ring pasregan / Badung temunang mangan agine seleregan / Ngunus keris gedan gendis kurang abyur

v) Kembang Waru

Kembang waru wite sampan geni seloko / Yo incek-incek doro widodari / Lenggung paying dadari kelangan tunjung / Yo tunjung-tunjung biru

w) Celeng Mogok

Celeng mogok keser-keseran / Sente jurang lemah auwur penganjaran

$\mathrm{x})$ Condro Dewi

Condro dewi murto siyem / Condro dewi murto siyem / Moro mundur / Moro mundur kembang petetan

y) Agung - Ageng

Agung-agung kulo nyuwun sepunten / Mendhung wetan mendhung kulon / Udan sore resa rese / Mendhung kidul mendhung ngalor / Udan sore resa rese

z) Erang-Erang

Erang-erang yo wong adang kayune merang / Mambu kukus-mambu kukus / Ketongkol gudeg wang bagus

aa) Gerang Welut

Gerang welut dibakar kari sak rambut / Diperketek-diperketek / Kadung demen tarinen dewek

bb)Emping-Emping

Empang-emping, emping-emping / Lare cilik manjer killing / Yo mudhuno yo puter keneng guno

cc) Upak Gadhung

Upak gadhung yo dibakar pating melenthung / Bengan-bengung polahe wong demen gandrung

dd)Liliro Gule

Liliro gule, sabuk-sabuk cinde ring gurase / Kakang yo ngeliliro jowo bendho ring seloko

ee) Sampun

Sampum mbah ketut sare / Sampun asang, yo kaundangan /Yo mullah mulih

Ada enam kegiatan dari 31 lirik lagu yang harus dilaksanakan pada pelaksanaan ritual setiap hari (selama 7 hari). Kegiatannya yaitu: 1) Pemasangan omprog (Mahkota) pada penari seblang oleh panikep, penari seblang memegang nyiru, pawing mulai membaca mantra memanggil roh leluhur dengan iringan gending seblang lakinto, apabila nyiru sudah jatuh

16 JURNAL LISAN AL-HAL 
berarti seblang sudah jadi (kemasukan roh) dalam keadaan tertidur ${ }^{14}, 2$ ) Dodol kembang dermo (jual bunga) dengan iringan gending kembang dermo, 3) Tunlikan (lempar sampur) mengajak tamu undangan, penonton untuk menari bersama diatas genjot dengan iringan gending layar kumendung, 4) Seblang menari mundur dengan iringan gending celeng mogok, 5) Seblang jatuh tengkurep dengan iringan gending condro dewi, dan 6) Seblang berpamitan dengan gending sampun embah ketut sare. Dari keseluruhan gending di atas merupakan mantra ritual yang berpengaruh terhadap gerak simbolis yang disampaikan oleh seblang.

\section{Pelaksanaan Tradisi Ritual Seblang}

Pelaksanaan tradisi ritual seblang di Desa Olesari Kecamatan Glagah Kabupaten Banyuwangi cukup panjang sepekan sebelum pelaksanaannya dan sepekan sesudah pelaksanaannya yang disebut bersih desa. Upacara bersih desa dilaksanakan dengan tujuan mengharap keselamatan desa dengan warganya oleh karena itu bersih desa juga disebut" selamatan desa". Bersih desa merupakan kepercayaan dari sekelompok komonitas dengan berbagai masalah yang berhubugan antara manusia dengan semua yang dengan arwah (gaib) yang dipercaya merupakan kekuatan lain di luar dirinya, komonitas yang melaksanakan bersih desa dalam upacara adat itu merupakan komonitas muslim, tetapi kepercayaan kepada kekuatan disekitarnya sangat dominan. Sebagian meyakini ritual itu hanya semacam sebagai produk budaya yang tidak terkait dengan agama. Sebab ritual itu bersumber dari kegiatan upacara yang diyakini masih tergantung pada tuhan atau pangeran. Oleh karena itu, selama bersih desa ada sesuatu kegiatan berdoa yang dilakukan berdasarkan syariat islam, berupa rasa syukur kepada Allah SWT dan kepada arwah leluhur atas segala usaha mereka dalam memenuhi kebutuhannya (pekerjaan). Terutama pertaniannya, bersih desa selalu diawali dengan"ider bumi (keliling kampung)"yaitu mengelilingi desa pada empat penjuru mata angin yang desebut puji desa, disetiap puji desa terdapat tempat yang dipercaya tempat bersemayamnya para arwah leluhur, seperti "makam buyut (makam leluhur)" atau pada tempat yang memiliki mata air (sumber).

Bersih desa yang dilakukan dengan ider bumi, biasanya dilakukan pada hari terakhir setelah upacara adat seblang menjelang "surup (terbenamnya matahari)" mengelilingi desa dan singgah dibeberapa tempat dan kembali ke panggung. Urutan prosesi yang harus dilaksanakan

14 Ibid 
ketika ider bumi, pawang yang bertugas mengundang arwah mengapit penari seblang dengan membawa perapen (dupa kemenyan), sedangkan para pesinden dan keturunan seblang berbaris dibelakangnya. Sambil melantunkan sair-sair seblang "layar kumendung" layar kumendung, ombak ring segara, segarane tuan agung, tumenggung nunggang kereta, yang artinya layar tertutup mendung, gelombang ombak hanya di samudra-samudra yang telah menjadi milik penguasa agung. Para tumenggung naik kereta, Apa yang menjadi latar belakang sya'ir itu dinyanyikan dalam upacara ider bumi, belum seorangpun yang bisa memberikan jawaban.

Upacara adat seblang didesa Olehsari terdiri dari empat tahapan. Yang pertama : penentuan hari pelaksanaannya dengan suatu proses yang disebut "kejimen". Pelaksanaannya dibuka dengan selamatan dalam persiapan "macaki genjot" yang merupakan tempat atau arena pelaksanaan seblang. Sedangkan penentuan hari pelaksanaan dilakukan minggu terakhir bulan puasa atau dua minggu sebelum hari pelaksanaan seblang. Penentuan hari itu dilakukan oleh seorang pawang yang mengundang arwah yang disebutnya "jin", melalui perantara seseorang yang dimasuki jin yang disebut "kejiman", upara mendatangkan arwah itu dilakukan di rumah seorang pawang dengan mengundang seluruh perangkat desa, tokoh masyarakat dan para sinden. Sebelumnya pawang mempersiapkan "perapen" yang dibuat dari serabut kelapa yang dibakar dan ditaburi kemenyan. Sehingga menimbulkan bau asap yang menyengat dan suasana yang wingit (menyeramkan). Kemudian pawang atau dukun membacakan beberapa bait mantra untuk mendatangkan "arwah" yang merasuk kedalam tubuh manusia yang ada didalam rumah itu, kemudian orang tersebut tidak sadarkan diri dan terjatuh di atas ranjang yang sudah disiapkan oleh pawang, kemudian orang tersebut bergetar-getar dan mengeluarkan ucapan-ucapan yang kurang di mengerti oleh orang-orang sekitarnya. Proses lebih lanjut pada tidak sadarnya orang yang kesurupan itu melakukan komunikasi melalui bahasa isyarat dengan gerakangerakan gemulai. Kadang-kadang menyanyikan bait-bait sair seblang dengan cara menggertak-gertak pada sesuatu yang kurang berkenan dan sulit di mengerti. Proses kejinan (kemasukan jin) sering dilakukan dua tiga kali, jika proses pertama belum menghasilkan suatu kepastian yang sesuai, baik tentang harinya maupun penari seblang. Penari seblang yang terpilih itu, merupakan keturunan dari penari seblang sebelumnya. Penari seblang biasanya seorang gadis remaja di bawah usia 13 tahun. 
Pergantian pemeran seblang biasanya selalu terpilih selama tiga tahun, pergantianya karena usianya sudah dewasa. Proses pergantianya sering terkendala kasus dengan berbagai alasan. Ketika lokasi tempat upacara adat dibangun oleh pemerintah tahun 2006 dalam bentuk arena, dukun dan penari seblang tidak bisa menggunakan arena itu dengan alasan mistis. Kemudian pada tahun 2008, gejala terlihat lebih jelas. Penari seblang selama tiga hari kesurupan, itu terjadi sesudah di tonton orang banyak. Berbagai alasan dilontarkan kepada panitia pelaksana yaitu adanya nuansa politik yang mewarnai, adanya orang-orang partai didalamnya, adanya bendera partai di sekitar arena. Sesungguhnya semua alasan itu kurang terbukti, sedangkan alasan yang kuat merupakan nilai mistik tentang tempat itu. Sebab pemerintah tidak mengajak bicara masyarakat ketika membangun pentasnya. Sehingga tiga bulan sesudah upacara adat seblang itu, lokasi arena yang dibuatkan oleh pemerintah dilakukan selamatan dengan harapan tahun-tahun yang akan datang tidak ada masah lagi. Kasus itu menimbulkan kesan tersendiri, bagi yang kurang mempercayai adat itu mengandung nilai magic yang dimiliki oleh pengikut adat seblang.

Pelaksanaan upacara adat seblang diselenggarakan selama seminggu berturut-turut dan dilanjutkan prosesi "ngelungsuri" atau penculikan yang dilakukan pada hari terakhir upacara adat seblang. Upacara adat seblang di desa Olehsari dimulai menjelang matahari lingsir (tergelincir) sampai surup (terbenamnya matahari). Mula-mula penari seblang di arak dari rumah pembuat omprok, setelah penari seblang di dandani, penari seblang yang diapit pawang atau dukun, rombongan itu bergerak menuju arena di iringi sejumlah pesinden dan penjamu. Di dalam iring-iringan itu ada orang pembawa payung warna kuning yang mamayungi penari seblang, sesampainya rombongan diarena pentas, penari seblang di dudukkan pada satu tempat yang telah disediakan dukun atau pawang, mendirikan penari seblang dengan membanting sebuah nyiru (nampan) yang melintang pada kedua tangan. Pawang membacakan mantra seraya mengenakan omprog di kepalanya dan memejamkan matanya.

Detik-detik itu merupakan peristiwa yang cukup menegangkan, sebab akan mengakibatkan persentuhan penari dengan kekuatan lain diluar dirinya. Puncaknya ketika nyiru atau nampan yang dipegang penari terjatuh dari pegangannya, maka penari seblang akan mengikuti iringan musik dan gending yang dimainkan para oga dan pesinden. Pada mulanya penari seblang mengikuti gerak para penjamu atau pengiring, setelah itu seblang melakukan gerakan berdasarkan gending yang dilantunkan para 
pesinden, seraya berputar-putar mengelilingi para penabuh yang berada di sekitar payung agung. Sesekali penari seblang berhenti pada posisi tertentu menghadap penonton untuk menghormati tamu yang melihat terutama tamu yang berderet di depan sebagai undangan. Didepan tamutamu itu penari seblang menari dengan gemulai sambil menghadap dengan anggukan atau berjabat tangan. Tarian diiringi oleh sejumlah gending, setiap gending yang dinyanyikan memiliki karakter yang tersendiri dari setiap tarian yang ditampilkan oleh penari seblang. Penari seblang akan berhenti dan kembali duduk di tempat yang telah disediakan di depan sinden apabila gending tidak dilantunkan. Dimana gending dan gerakan penari seblang merupakan sebuah pantonim atau gambaran sejarah dalam penampilannya. Seperti halnya gending kembang dirma "merupakan gending interaksi" antara penari seblang dengan penonton dengan cara menjual bunga, menurut kepercayaan masyarakat jika bunga yang dijual itu mengandung nilai mejic, berbagai peruntungan untuk memperoleh rezeki, jodoh, kedudukan, keselamatan, dan lain sebagainya. Dari bunga yang di jual di dasarkan pada perhitungan pasar, bunga tusuk itu dibuat oleh keluarga penari seblang dirangkai begitu rupa dan disisipi bunga kenanga, kantil, dan pecari ditusukkan pada irisan belahan bambu pecah tiga pada saat menjual bunga itu, dengan diiringi lantunan gending "layar kumendung" penari seblang diatas altar atau ranjang bambu, melemparkan sampur atau selendang kearah penonton. Untuk ikut menari bersama diatas altar, pelemparan sampur itu di sebut "cundik". Bagi penonton yang terkena lemparan cundik, harus naik kealtar untuk menari bersama, namun ketika penonton yang terkena lemparan cundik memiliki penilaian yang kurang baik terhadap penari seblang, ketika berdiri bersama dengan penari seblang diatas altar, yang bersangkutan tidak mampu menari justru di tempelengi oleh penari tanpa bisa mengelak atau turun dari altar.

Pada saat dilantunkan "celeng mogok" penari seblang menari mundur atau menengadahkan wajahnya keatas. Dari sekian banyak gerakan tari pada upacara adat seblang. Gending yang membuat penonton bersedih dan menangis adalah gending "candra dewi" sebab penari jatuh terhempas pingsan, disaat itu penonton sama-sama berhamburan naik kearena untuk memberikan "sedekah" berupa uang recehan yang ditempatkan pada tempayan dengan harap-harap cemas "penari seblang bisa sadarkan diri" 15 .

15 Ibid.

20 JURNAL LISAN AL-HAL 


\section{Tradisi Seblang dalam Pandangan Hukum Islam}

Secara umum seblang adalah suaatu tradisi yang dilakukan oleh sebagian mansyarakat banyuwangi yang memiliki nilai dan maksud tertentu tertentu yaitu: 1) Sebagai wadah ekspresi keagamaan, 2) Emosi keagamaan, 3) Sebagai sistem kepercayaan atau bayang-bayangan manusia tentang bentuk dunia, alam gaib, hidup, maut, 4) Sebagai acara keagamaan yang bertujuan mencari hubungan dengan dunia gaib berdasarkan sistem kepercayaan, 5) Sebagai alat pengikat kelompok, dan 6) Sebagai benteng pertahanan kelompok.

Beberapa nilai yang dikandung oleh seblang tersebut memiliki tujuan yang baik yang tentunya tidak bertentangan dengan ajaran agama Islam sebagai agama yang baik. Sebagaimana yang diterangkan bahwa segala sesuatau itu tergantung pada niatnya apabila niatnya baik maka diperbolehkan oleh syari'at Islam sebaliknya apabila niatnya buruk maka tidak diperbolehkan.

Pada sisi lain seblang ada sebagai urf atau adat yang ada sejak dahulu yang menjadi kebiasaan mayarakat Banyuwangi, dengan kata lain masyarakat Banyuwangi melakukan tradisi adat seblang tersebut dan menganggap boleh tradisi tersebut, hal tersebut dapat dikaitkan dengan keterangan yang dikemukakan oleh Imam As-Sarkhasi. Imam As-Sarkhasi dalam kitab "al-Mabsudh" mengemukakan:".

$$
\text { الثَابِتُ بِالعُرْفِ كالنَابِتِ بِالنَّصِّ }
$$

"Apa yang di tetapkan berdasarkan 'Urf statusnya seperti yang ditetapkan berdasarkan Nash".

Yang dimaksud oleh Imam as-Sarkhasi ialah bahwa apa yang ditetapkan berdasarkan 'Urf sama dengan yang ditetapkan berdasarkan dalil syar'i yang sederajat dengan nash sekiranya tidak terdapat nash. ${ }^{16}$

Seblang termasuk urf yang Khas karena hanya dilaksanakan atau diselenggarakan oleh masyarakat Banyuwangi sebagaimana keterangan bahwa 'Urf Khas adalah kebiasaan yang tidak dikenal oleh semua kalangan namun hanya sekelopok tertentu. Sebagaimana ungkapan-ungkapan yang biasa terlontar dalam kebiasaan syara' idiom-idiom dari sekelompok tertentu, seperti istilah rafa' dalam kebiasaan penyebutan pakar nahwu. ${ }^{17}$

Seblang juga dapat digolongkan terhadap Urf Mutabaddil karena bersifat dinamis yang bisa berubah seiring dengan berubahnya ruang dan waktu dan tidak bersifat taklifi sebagaimana yang diterangkan 'Urf 416-418.

16 Muhammad Abu Zahrah, Ushul Fiqh, (Jakarta: PT.Pustaka firdaus, 2010.), hlm.

17 Maimoen Zubair, Formulasi Nalar Fiqh.(Surabaya: Khalista, 2005), hlm. 218. 
Mutabaddil ialah tradisi yang dinamis, dapat berubah karena perbedaan ruang, pergantian waktu, dan perubahan kondisi. Sebagaiman tanpa penutup kepala bagi orang-orang terhormat. Di negeri-negeri timur hal ini dianggap buruk dan akan mengurangi kehormatannya. Namun di negerinegeri barat, hal ini lumrah terjadi dan bukanlah hal yang buruk. ${ }^{18}$

Hal yang terpenting adalah bahwa seblang termasuk urf sahih, 'Urf yang shahih atau al-Adah Ashahihah yaitu 'Urf yang tidak bertentangan dengan syari'ah, ${ }^{19}$ yang didalamnya memiliki nilai-nilai yang islami meski dalam pelaksanaannya masih mengikuti tata cara yang dilakukan oleh masyarakat hindu pada masa dahulu nenek moyang mereka. Itu dapat dilihat dengan adanya selametan tumpengan dengan masyarakat desa yang dilakukan di makam nenek moyang dengan melakukan tahlil bersama sebelum pelaksanaan. Yaitu pada malam sebelum pementasan atau H-1. Dan juga tidak bertentangan dengan syariat Islam tidak menghalalkan yang haram atau sebaliknya mengharamkan yang halal.

\section{E. Simpulan}

Dari hasil peneltian di desa olehsari kec. Glagah kab. Banyuwangi tentang tradisi ritual seblang, maka dapat diperoleh kesimpulan sebagai berikut :

1. Pelaksanaan ritual tarian seblang dilakukan dengan dua tahapan, yang pertama tahapan persiapan dimana pelaksanaan dilakukan pada sepekan sebelum hari raya, yang kedua tahapan pelaksanaanya yaitu ketika mendapat petunjuk, dan dilakukan selama sepekan, biasanya dilakukan setelah hari raya dapat tiga atau empat hari.

2. Perspektif hukum Islam terhadap tradisi ritual tarian seblang dihukumi boleh, karena beberapa alasan yaitu memiliki tujuan yang luhur, seblang termasuk urf mutabaddil yang bisa berubah dan tidak bersifat taklifi, seblang adalah termasuk urf sahih yang tidak bertentangan dengan syariat Islam yaitu tidak menghalalkan yang haram dan tidak mengharamkan yang halal.

18 Maimoen Zubair, Formulasi Nalar Fiqh.(Surabaya: Khalista, 2005), hlm. 218-219.

${ }^{19}$ H. Adjazuli, Ilmu Fiqih, (Jakarta: Prenada Media Group, 2006), hlm. 90. 


\section{DAFTAR PUSTAKA}

Abu Zahrah, Muhammad. Ushul Fiqh, Jakarta: PT.Pustaka firdaus. 2010.

Ali Riyadi, Ahmad. Dekontruksi Tradisi. Yogyakarta: Ar-Ruzz, 2007.

Arikunto, Suharsimi. Prosedur Penelitian Suatu Pendekatan Praktik. Jakarta: PT. Rineka Cipta. 1996.

Arikunto, Suharsini. Prosedur Penelitian Suatu Pendekatan Praktek, Jakarta: PT. Rineka Cipta. 2002.

B. Miles, Matthew. Analisis Data Kualitatif. Jakarata: UI-Press. 1992.

Bachtiar, Hartono. Dasar-dasar ilmu hukum, Surabaya: Al-Right Resrfed. 1998.

Bakry, Nazar. Fiqh dan Ushul Fiqh. Jakarta: PT. Raja Grafindo Persada. 2003.

Bawani, Imam. Tradisionalisme dalam pendidikan Islam. Surabaya: Al Ikhlas. 1990.

Bisri, Moh. Adib. Terjemah Al Faraidul Bahiyyah, Rembang: Menara Kudus. 1977.

DEPAG RI. al-Qur'an dan Terjemah, Jakarta : Mujamma'al-Malik Fahdli li Thiba'at al-Mush-haf Asy-Syarif. 1990.

H. Adjazuli, Ilmu Fiqih. Jakarta: Prenada Media Group. 2006.

Ibrahim Muhammad, Mahmud. Al-Madkhal ila Al-Qawa'id Al-Fiqhiyah AlKulliyah. Dar 'Aman. 1998.

id.m.wikipedia.org/wiki/Tradisi

Ifrosin, Fiqh Adat (tradisi masyarakat dalam pandangan fiqh). Jawa Tengah: Mukjizat. 2007.

Kholaf, Abdul Wahab, Ilmu Ushul Fiqh, Kuwait: Darul Ilmi. 1978.

Koentjaraningrat, Pengantar Ilmu Antropologi. Jakarta: PT Rineka Cipta. 2009.

M. Setiady, Elly. dkk, Ilmu Sosial dan Budaya Dasar, Jakarta: Kencana Pernada Media. 2006.

Mahfudh, Sahal, Kilas Balik Teoritis Fqih Islam. Kediri: Madarasah Hudayatul Mubtadi-ien, 2004.

Moleong, Lexy J. Metodologi Penelitian Kualitatif. Bandung: PT. Remaja Roesdakarya Offset. 2011.

Satori, Djam'an. Metodologi Penelitian Kualitatif . Bandung: Alfabeta. 2010.

Satori, Djam'an. Metodologi Penelitian Kualitatif . Bandung: Alfabeta. 2010.

Shihab, M.Quraish, Tafsir Al-Misbah Volume 4, Ciputat:Lentera Hati. 2009.

Subhani, Ja'far. Tauhid dan Syirik, Bandung: Mizan, 1994.

Syafe'I, Rachmat. Ilmu Ushul Fiqih, Bandung: CV. Pustaka Setia. 2010.

Syamsuddin, Din. Etika agama dalam membangun masyarakat madani, 


\section{"Tradisi Ritual Seblang"}

Jakarta: PT Logos, wacana ilmu. 2000.

Tim Penyusun, Pedoman Penulisan Karya Ilmiah. Sukorejo: IAI Ibrahimy Situbondo. 2010.

Wignjodipoero, Soerojo. Pengantar Dan Asas-Asas Hukum Adat, Jakarta: CV. Haji. Masagung. 1988.

www.himmaba.com/2013/03/pengertian-dan-perbedaan-adat Zubair, Maimoen. Formulasi Nalar Fiqh. Surabaya: Khalista, 2005.

Zuriyah, Nurul. Metodologi Penelitian Sosial dan Pendidikan. Jakarta: PT Bumi Aksara, 2006. 
